\title{
Eliciting Stakeholder Needs - An Anticipatory Approach Assessing Enhanced Landfill Mining
}

Paul EINHÄUPL ${ }^{\mathrm{a}, \mathrm{b}}$, Joakim KROOKc, Niclas SVENSSONc, Karel VAN ACKER ${ }^{\mathrm{a}, \mathrm{d}}$, Steven VAN PASSEL ${ }^{\mathrm{b}}$

${ }^{a}$ Department of Materials Engineering, Faculty of Engineering Science, KU Leuven, Kasteelpark Arenberg 44, 3001 Leuven Belgium.

${ }^{b}$ Department of Engineering Management, Faculty of Applied Economics, UAntwerpen, Prinsstraat 13, 2000 Antwerp, Belgium.

'Department of Management and Engineering, Environmental Technology and Management, Linköping University, Hus A, 3A, 58183 Linköping Sweden.

dResearch Centre for Economics and Corporate Sustainability (CEDON), KU Leuven, Warmoesberg 26, 1000 Brussels, Belgium.

apaul.einhaeupl@kuleuven.be (corresponding author), +32 326591 09;

cjoakim.krook@liu.se;

cniclas.svensson@liu.se;

akarel.vanacker@kuleuven.be;

bsteven.vanpassel@uantwerpen.be 


\section{Abstract}

Landfill owners, governmental institutions, technology providers, academia and local communities are important stakeholders involved in Enhanced Landfill Mining (ELFM). This concept of excavating and processing historical waste streams to higher added values can be seen as a continuation of traditional landfill mining (LFM) and seems to be an innovative and promising idea for potential environmental and societal benefits. However, ELFM's profitability is still under debate, and environmental as well as societal impacts have to be further investigated. This study provides a first step towards an anticipatory approach, assessing ELFM through stakeholder integration. In the study, semi-structured interviews were conducted with various stakeholders, involved in a case study in Flanders, Belgium. Participants were selected across a quadruple helix $(\mathrm{QH})$ framework, i.e. industrial, governmental, scientific, and local community actors. The research comprises 13 interviews conducted with an aim to elicit stakeholder needs for ELFM implementation using a general inductive approach. In total 18 different stakeholder needs were identified. The paper explains how the stakeholder needs refer to the different dimensions of sustainability, which groups of stakeholders they primarily affect, and what types of uncertainty could be influenced by their implementation. The stakeholder needs are structured into societal, environmental, regulatory and techno-economic needs. Results show additional economic, environmental, and societal aspects of ELFM to be integrated into ELFM research, as well as a need for the dynamic modeling of impacts.

\section{Keywords}

Enhanced Landfill Mining, stakeholder needs, anticipatory approach, sustainability, circular economy. 


\section{Introduction}

Recent landfill mining (LFM) research has focused on the processing of waste to higher added values, and a new approach to mining landfills has emerged, leading to the concept of enhanced landfill mining (ELFM): ELFM aims to add value to past urban waste streams as materials (Wasteto-Material, WtM) and energy (Waste-to-Energy, WtE), using innovative technology in an integrated and environmentally and socially sound way (Jones et al., 2013). Aside from (geo)strategic considerations, potential environmental, economic, and societal benefits have made ELFM an appealing, but complex, concept for research, industry, and policymakers.

The aim of this study is to integrate stakeholders into ELFM assessment in order to identify knowledge gaps and uncertainties related to ELFM implementation through eliciting stakeholder needs. A broad stakeholder integration will enable ELFM research to better understand the structure of technology-, market, or regulatory-related uncertainties, and will enable policymakers and industrial actors to make more informed decisions. To tackle this challenge, we apply an anticipatory approach, which gives specific attention to the integration of stakeholder values and the inclusion of uncertainty through the use of prospective modeling tools and multiple social perspectives (Cucurachi et al., 2018; Wender et al., 2014).

Within this approach, analyzing stakeholder needs is a necessary first step to enable a sensible ELFM implementation. In the context of this study, stakeholder needs are defined as expectations and requirements that various ELFM practitioners and affected groups or individuals have towards ELFM implementation. To elicit these stakeholder needs we have conducted semistructured interviews and analysis following a general inductive approach, which aims to derive 
concepts, themes or models from textual data to create meaning (Thomas, 2006). A well-studied ELFM case in Belgium provides the basis for a broad and accessible stakeholder environment, and the required scientific context to reasonably interpret results.

\section{State of the Art}

The State of the Art section reviews the current literature in ELFM research and explains how stakeholders have been integrated. It summarizes how uncertainty is treated throughout this research and gives a short overview of the regulatory framework for ELFM.

\subsection{ELFM Research and Stakeholder Integration}

Former research on LFM has generally been approached with a focus on solving landfill management issues, mainly landfill air space recovery, pollution concerns, and material characterization. Krook et al., (2012) give a well-established overview of research over the prior two decades. Since then, the concept of LFM has developed to ELFM and the focus has shifted to technological challenges as well as economic and environmental assessments of ELFM projects (Jones et al., 2013; Krook et al., 2018b). Nonetheless, material composition, especially the fine fraction, still plays a crucial role in the valorization of landfilled waste (Burlakovs et al., 2018; Hernández Parrodi et al., 2018), alike WtM (Garcia Lopez et al., 2018), and WtE (Bosmans et al., 2013) technology.

Assessments are usually performed either on an ex-ante basis or from small-scale pilot projects (Krook et al., 2018b). All dimensions of sustainability, i.e. economic, environmental, and societal, are assessed but a clear focus lays on economic and environmental issues. Societal factors are, 
to some extent, evaluated through integrated assessments but ELFM research generally lacks assessment models in this area.

Economic studies on ELFM usually take a private investor's perspective, using some form of cost and benefits aggregation like the net present value (NPV) (Danthurebandara et al., 2015a; Wagner and Raymond, 2015), and are showing mixed results depending on technology (e.g. mobile vs local separation) or methodological choices (e.g. resource prices) (Van Passel et al., 2013; Zhou et al., 2015). However, overall studies show a tendency for ELFM not being profitable. Some economic assessments integrate a societal perspective by contrasting private and public scenarios (Winterstetter et al., 2018, 2015) or the monetization of environmental externalities (Van Passel et al., 2013). The dominant method to evaluate the environmental dimension of ELFM is life cycle assessment (LCA) (Danthurebandara et al., 2015b; Frändegård et al., 2013a; Gusca et al., 2015; Jain et al., 2014; Pastre et al., 2018). Results show potential benefits but also generated burdens.

The integration of stakeholders has only been touched upon superficially by ELFM research; it is usually not carried out in a comprehensive manner and includes only selected experts. Johansson et al. (2012) studied five different landfills in Sweden to identify key challenges and critical factors for a shift towards (E)LFM implementation, and conclude that exogenous changes, e.g. legislation, might be necessary. They integrate the project owners through interviews and other industrial stakeholders through historical documents such as old invoices and shipping documents to provide a historical overview of the landfill structure (Johansson et al., 2012). Similarly, a later study interviews experts from a recycling company and integrates institutional 
stakeholders through legislative texts (Johansson et al., 2017). Hölzle (2019) includes a broader range of stakeholders for a material flow analysis (MFA). Furthermore, he investigates influencing factors and uses various documents, including regulations and reports from engineering consultants and environmental agencies, amongst others, as well as stakeholder interviews to conduct a PEST (political, economic, socio-cultural and technological) analysis. He identifies a large variety of factors in the categories of landfill, technology, economy, organization and institutions/laws (Hölzle, 2019). Hermann et al. (2016) develop a decision-making procedure also using interviews and focus groups with institutional and industrial experts along the value chain of ELFM. They combine economic and environmental assessments and integrate the societal dimension into a holistic model. They derive four socio-economic criteria, i.e. interests of operators, neighbors, and authorities, as well as the space required for conversion of the landfill. This preliminary assessment, using a ranking system, is carried out by means of a questionnaire to derive utilities that again serve as input data for the main assessment, where effects become entangled (Hermann et al., 2016b, 2015). Two other studies use contingent valuation methods (CVM) to monetize societal benefits (Damigos et al., 2015; Marella and Raga, 2014). Marella and Raga (2014), for example, use willingness-to-pay (WTP) to assess the welfare increase through the creation of a public park after ELFM operations and calculate a surplus of about 200 euros per capita. These studies include community actors through questionnaires but are based on hypothetical scenarios and the derived monetary values comprise multiple societal effects (Marella and Raga, 2014). Pastre et al. (2018) also consider communities in their assessment tool for ELFM in the form of a ranking system for societal factors, but stakeholders have not been involved in the development of the tool. 


\subsection{Uncertainty in ELFM Research}

Most case studies on the performance of ELFM have a prospective character, assessing potential future outcomes. Additionally, different methodological choices and case-specific circumstances affect their comparability (Krook et al., 2018b). These include site-specific issues like waste composition, technology choices or contextual factors, and often limit the generalization of results. In consequence, the general results of ELFM studies are subject to considerable uncertainties.

In some studies, different types of uncertainties are mentioned. These are mostly market (van der Zee et al., 2004), technology (Frändegård et al., 2013b), or society (Pastre et al., 2018) related. Several studies, however, do address uncertainty through sensitivity analyses. Economic costs and benefits or the variation of NPVs due to market uncertainties (e.g. material, electricity or land prices) are analyzed (Danthurebandara et al., 2015a; Kieckhäfer et al., 2017; Van Passel et al., 2013; Winterstetter et al., 2015), as well as variations of environmental factors affecting greenhouse gas (GHG) emissions, for example (Frändegård et al., 2015, 2013b; Laner et al., 2016). Bobe and Van De Vijver (2019) already take uncertainty into account during the exploration phase and therefore make it clear that data along all stages of ELFM assessment should be treated probabilistically rather than deterministically. However, to understand the relationship between different factors, as well as the distributions, is crucial since a bad choice in probability distributions could lead to overall more uncertainty. Moreover, types of uncertainty are not differentiated, nor their interaction with each other. 


\subsection{The Regulatory Situation of ELFM}

In Europe, the so-called Landfill Directive sets the standard for managing current landfills (Council Directive, 1999). Amongst other areas, it regulates operational, financial, and safety issues. During operations, a landfill runs through several stages: the landfilling period, the after-care period, and the release from after-care (Council Directive, 1999). In case of ELFM implementation, conceptually, a mining and an after-use period would be added. Additionally, the Landfill Directive sets regulations for safety and sanitary landfill design, including liners and LFG collection systems, for example (Council Directive, 1999). Regulations for the treatment of hazardous waste are further defined in the Waste Directive (Council Directive, 2008). A large number of landfills predating these directives, however, cannot be considered sanitary and might pose potential risks (Jones et al., 2013; Krook et al., 2018a). They are commonly referred to as “Dump Sites".

In May 2017 the European Council has rejected the ELFM Amendment to the Landfill Directive (Jones et al., 2018) making the regulatory situation for ELFM somewhat vague. Yet the answer of the European Commission (EC) to a parliamentary question states that "Landfill mining is [...] not prohibited [...]" (Jones et al., 2018). A legal report for the Austrian LAMIS project supports that statement and concludes that the current legal framework does not hinder ELFM operations, even at a larger scale (Eisenberger, 2015). In Flanders, OVAM, the environmental agency is responsible for soil remediation, waste, and sustainable materials management, and also in charge of Flemish landfill regulations. A vision on ELFM was approved by their board of directors in 2011 (Behets et al., 2013). The Flemish Coalition Agreement 2014-2019 mentions the recovery of resources from landfills (Wille, 2016) and OVAM is developing a database on the current 
landfill situation, including contamination risks and resource potentials (Winterstetter et al., 2018).

\section{Method and Materials}

Eliciting stakeholder needs was an iterative process, starting with a literature review. From the gained knowledge, an interview guide was developed and potential interviewees identified. Two rounds of interviews were conducted. The interviews were recorded and transcribed, and analysis was carried out eliciting stakeholder needs. A schematic representation of the various steps involved in this method can be found in Figure 1. This section further describes the case study as well as the stakeholder selection. 


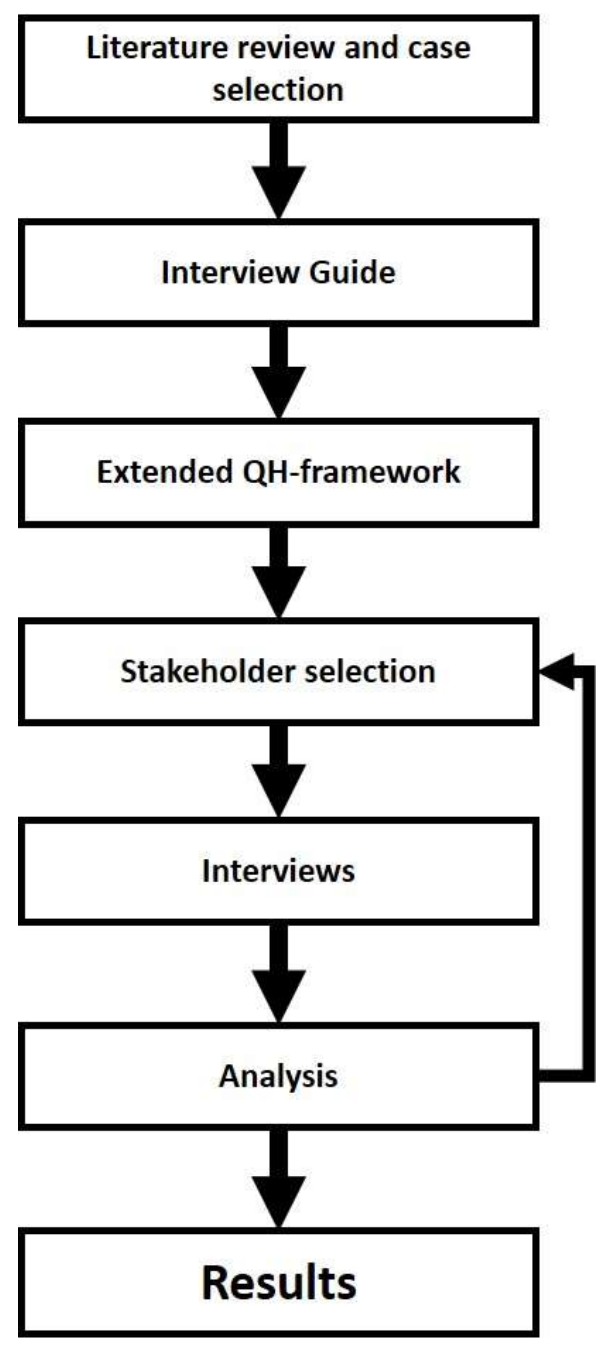

Figure 1: A schematic representation of the methodological approach. 


\subsection{Stakeholder Identification}

A combined quadruple helix $(\mathrm{QH})$-value chain framework provided the basis for the initial stakeholder identification. The $Q H$ approach distinguishes between various actors at different points of innovation processes to capture multiple, reciprocal relationships between them (Arnkil et al., 2010; Kolehmainen et al., 2016). In the context of this study, it included actors from (i) local communities, (ii) institutions, (iii) industry, and (iv) research. Stakeholders were further subcategorized by adding new levels of differentiation along the value chain of ELFM. Industrial actors were subclassified into operators, technology providers, and buyers. The extended QHvalue chain-framework is illustrated in Figure 2. Preliminary results contributed to an additional stakeholder selection: During the interviews, new potential participants were identified using respond-driven sampling, i.e. snowballing (Goodman, 1961; Heckathorn, 1997). A second round of interviews was conducted and the analysis finalized. 


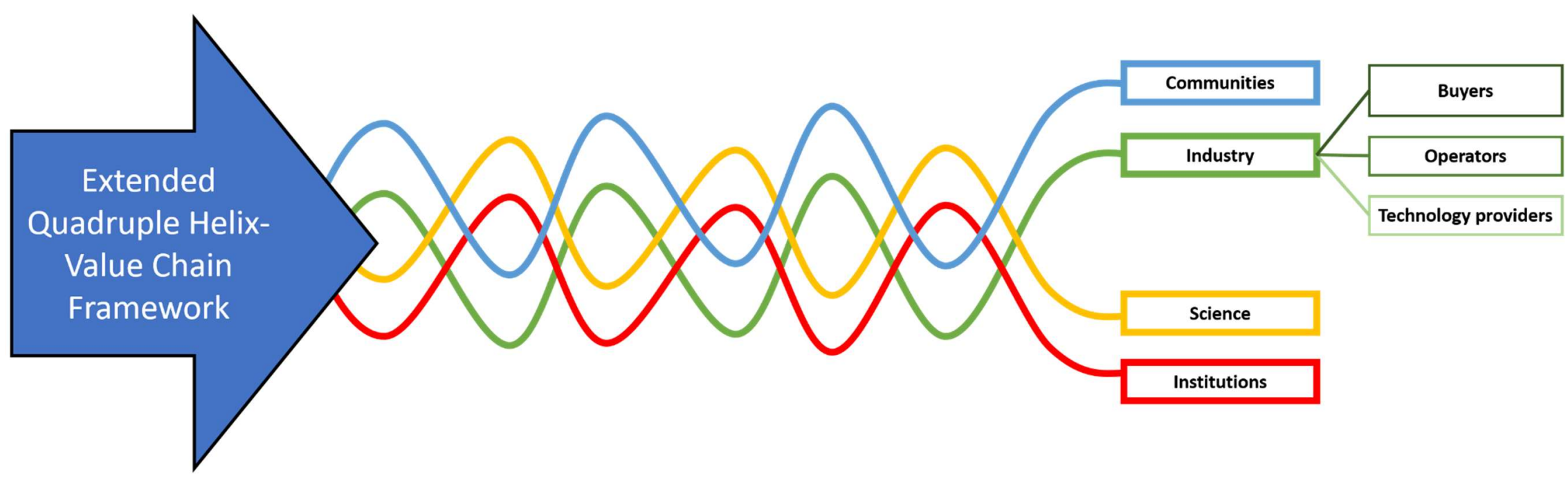

Figure 2: The Quadruple Helix-Value Chain Framework. 
3 For analysis, a general inductive approach was used, including three major steps, in which the

4 raw data is condensed into a brief summary format, clear links and relations are established

5 between the findings and the research objective, i.e. stakeholder needs, and a theoretical

6 framework about the underlying structure is developed (Thomas, 2006). Interviews were taken

7 in person or by phone. To elicit the stakeholder needs, interviewees were not just simply asked

8 directly. Open questions about landfills, ELFM in general, and the case study were used and needs

9 derived at a later stage. A list of these questions can be found in the Appendix. To process the

10 large amount of data (c.f. Section 4) QSR International's NVivo 11 software was used. This

11 enabled us to easily structure and extract relevant statements through coding, which established

12 links and relations between specific stakeholders or stakeholder groups, and statements. Coding

13 categories were adapted and refined throughout the analysis (Stemler, 2003; Thomas, 2006).

14 Overlapping coding was allowed, opening up the possibility of one statement being assigned to

15 several coding categories, hinting to links between them. In practice, statements and ideas

16 mentioned by participants were assigned to specific coding (sub)categories and linked to their

17 stakeholder group. An overview of the coding categories can be seen in Figure 3. Statements,

18 expressing stakeholder needs, were then summarized in tables and grouped thematically to

19 derive more general themes of interest. Through the coding, it was possible to derive which

20 stakeholder needs refer to different dimensions of sustainability and to identify the range of

21 effects in case of implementation of a need, i.e. perceived effects on stakeholders and regions.

22 Linking the stakeholder needs to different sustainability dimensions will reveal inter-dimensional

23 relations and help to identify potential trade-offs. How the implementation of the stakeholder 
24 needs will affect economic, environmental and societal impacts is explained in more detail 25 throughout the text (cf. Section 4).

26 To identify critical factors for uncertainties, consequently reduce the level of uncertainty in ELFM, 27 and facilitate its further development, it is important to differentiate and assess how various 28 processes are affected as well as how different types of uncertainty interplay with the 29 stakeholder needs. Five different types of uncertainty are differentiated: Technological uncertainty (TU) describes the influence of unknown factors on future technological innovation,

31 while market uncertainty (MU) describes unknown market-related effects. Regulatory 32 uncertainty $(R U)$ is derived from doubts about future regulatory frameworks, whereas 33 environmental uncertainty (EU) expresses unknown variations of environmental burdens and 34 benefits. Finally, social uncertainty (SU) is defined as the influence of unknown factors on the 35 social benefits and burdens of a project. These definitions are derived from various references 36 and adapted to fit the purpose of this study (c.f. Hoffnmann et al., 2009; Refsgaard et al., 2007; 37 Seidl and Lexer, 2013). 


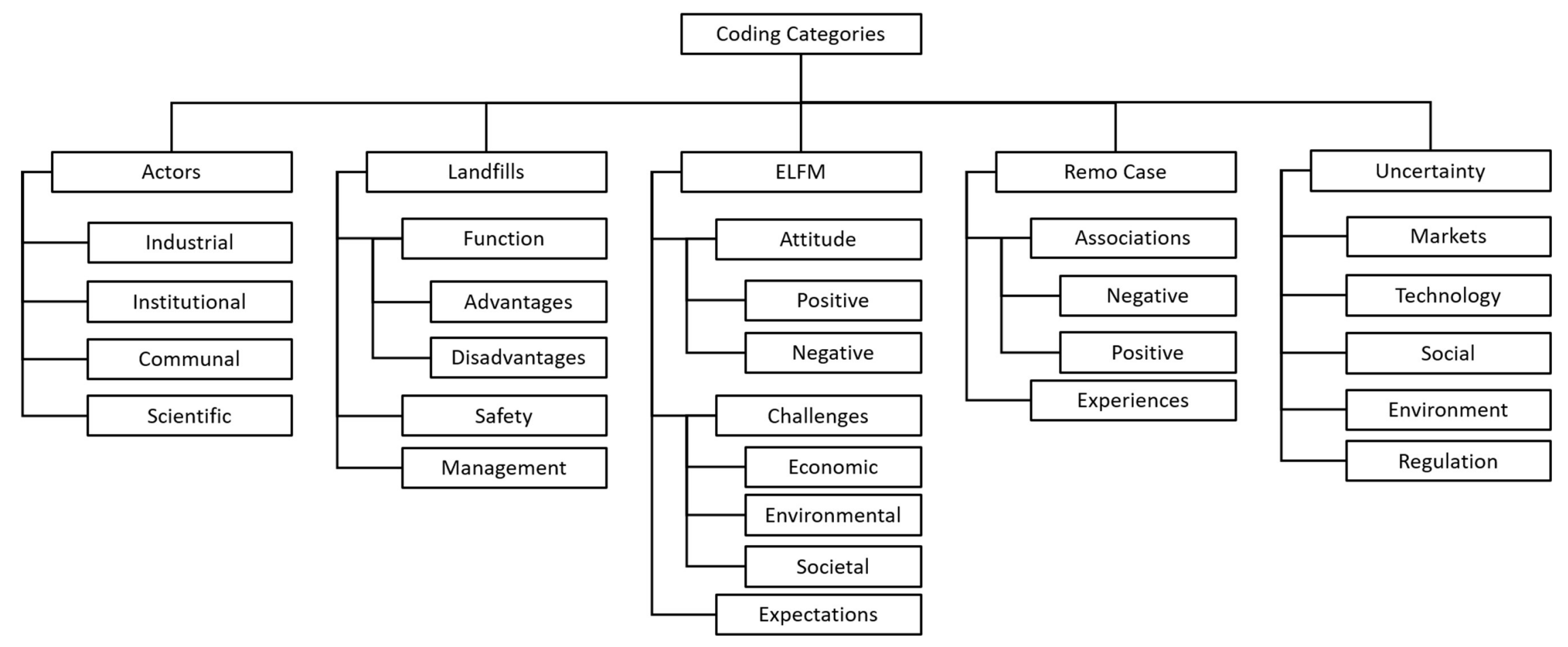

Figure 3: The emerged coding categories. 


\subsection{Case study and Sampling}

It was considered important to choose interviewees with active engagement in an applied ELFM case. This would enable participants having actual experiences and consider real implications of their statements, rather than hypothetical ones to increase the relevance of results (Bryson, 2004; Prell et al., 2008). The case should provide a broad stakeholder environment and should be subject to prior scientific research.

\subsubsection{The Remo Case}

The Remo landfill, located in the Flanders region of Belgium, generally meets these conditions (Bosmans et al., 2013; Danthurebandara et al., 2013; Quaghebeur et al., 2013; Van Passel et al., 2013). The landfill lies within a densely populated area and is surrounded by several smaller communities (Geysen, 2017; Group Machiels, 2018; Quaghebeur et al., 2013). In 2008 the "Closing the Circle" (CtC) project was introduced by the operators, aiming to establish ELFM operations at an industrial scale at Remo (Group Machiels, 2018). Permitting processes have started and the operators are in contact with the relevant institutions. These plans grabbed the attention of local citizens. Members of the surrounding communities are self-organized in a group called "De Locals". This group seeks to gather information about the planned ELFM activities at Remo and distribute it amongst residents. They have been following the ELFM project at Remo critically for about 7 years (Ballard et al., 2018).

\subsubsection{Stakeholder Selection}

The Remo case involves stakeholders from all four QH-classes. An approximate evenly distributed share of participants over the $\mathrm{QH}$-classes and a high level of case-involvement were prioritized criteria for the first selection of interviewees. The initial group of participants was selected by the 
62 researchers and aimed at the core stakeholders. It comprised eight interviews, including two

63 members of "De Locals", two actors from the regional waste agency, one European policymaker,

64 one researcher, and two managers from the operating company. Five additional interviews were

65 held in the second round. These included one community member, a leading member of the local

66 government, and two actors from technology providers being part of the CtC project.

67 Including buyers of ELFM products was a difficult task for two main reasons: First, as operations

68 have not started, no actual buyers exist; second, the wide range of outputs ELFM might be

69 offering is still subject to investigations. It is unclear, which technological and economic way ELFM

70 will take, and thus, difficult to identify potential customers for ELFM products (cf. Van Passel et

71 al. 2013; Bosmans et al. 2013; Krook et al. 2018). To compensate this gap, one additional

72 interview was held with a manager from an energy and recycling technology incubator, working

73 closely with potential purchasers of ELFM products and operating within a similar region. An

74 overview of all participants can be found in Table 1.

75 
Table 1: Interviewees sorted by stakeholder class.

\begin{tabular}{|c|c|c|c|}
\hline QH-Value Chain-Class & Stakeholder & $\mathbf{N}$ & \\
\hline \multirow[t]{2}{*}{ Community members } & & & 3 \\
\hline & De Locals & 3 & \\
\hline \multirow[t]{4}{*}{ Institutional actors } & & & 4 \\
\hline & Local Government & 1 & \\
\hline & Waste Agency & 2 & \\
\hline & European Government & 1 & \\
\hline \multirow[t]{2}{*}{ Scientific actors } & & & 1 \\
\hline & Researcher & 1 & \\
\hline \multirow[t]{4}{*}{ Industrial actors } & & & 5 \\
\hline & Operators & 2 & \\
\hline & Technology providers & 2 & \\
\hline & Technology incubator & 1 & \\
\hline
\end{tabular}

Total

77 
784 Results

79 The interviews took on average 54 minutes. The raw textual data comprised over 70.000 words.

80 In total 18 different stakeholder needs were identified. The analysis led to the categorization of

81 stakeholder needs into four major clusters: (i) societal needs, (ii) needs for environmental

82 benefits, (iii) regulatory needs, and (iv) techno-economic needs. This section is structured

83 accordingly. The last sub-section treats the five types of uncertainty (c.f. Section 3.2). An overview

84 of the stakeholder needs can be found in Table 2. 


\begin{tabular}{|c|c|c|c|c|c|c|}
\hline No. & Category & Stakeholder Need & Stakeholders & $\begin{array}{l}\text { Affected } \\
\text { sustainability } \\
\text { dimension }\end{array}$ & Range & $\begin{array}{l}\text { Affected } \\
\text { types of } \\
\text { uncertainty }\end{array}$ \\
\hline 1 & \multirow{5}{*}{ Societal needs } & $\begin{array}{l}\text { Protection against } \\
\text { disamenities }\end{array}$ & \multirow{2}{*}{$\begin{array}{l}\text { Community } \\
\text { members }\end{array}$} & $\begin{array}{l}\text { Econ., Env., } \\
\text { Soc. }\end{array}$ & Local to regional & SU, EU, RU \\
\hline 2 & & Employment & & Econ., Soc. & Local to regional & $\mathrm{SU}, \mathrm{MU}$ \\
\hline 3 & & Communal benefits & $\begin{array}{l}\text { Community } \\
\text { members and } \\
\text { local } \\
\text { government }\end{array}$ & Econ., Soc. & Local to regional & SU \\
\hline 4 & & Stakeholder involvement & \multirow[b]{2}{*}{ All stakeholders } & Econ., soc. & Local to global & $\mathrm{SU}, \mathrm{MU}$ \\
\hline 5 & & Safety & & $\begin{array}{l}\text { Econ., Env., } \\
\text { Soc. }\end{array}$ & $\begin{array}{l}\text { Regional to } \\
\text { supranational }\end{array}$ & $S U, R U$ \\
\hline 6 & \multirow{3}{*}{$\begin{array}{l}\text { Environmental } \\
\text { Needs }\end{array}$} & Avoided Impacts & All stakeholders & Env., Soc. & Local to global & EU, SU \\
\hline 7 & & $\begin{array}{l}\text { Mitigation of systematic } \\
\text { risks }\end{array}$ & \multirow[t]{2}{*}{$\begin{array}{l}\text { Regional waste } \\
\text { agency }\end{array}$} & $\begin{array}{l}\text { Econ., Env., } \\
\text { Soc. }\end{array}$ & Regional & EU, RU \\
\hline 8 & & Landfill conversion & & Env., Soc., & Local to regional & EU, SU \\
\hline 9 & $\begin{array}{l}\text { Regulatory } \\
\text { needs }\end{array}$ & Regulatory changes & $\begin{array}{l}\text { Industrial, } \\
\text { institutional and } \\
\text { scientific actors }\end{array}$ & Econ., Soc. & $\begin{array}{l}\text { Regional to } \\
\text { supranational }\end{array}$ & SU, RU, EU \\
\hline
\end{tabular}


10

11

12

\begin{tabular}{|c|c|c|}
\hline 13 & & Economic growth \\
\hline 14 & & $\begin{array}{l}\text { Technological } \\
\text { development }\end{array}$ \\
\hline 15 & $\begin{array}{l}\text { Techno- } \\
\text { economic } \\
\text { needs }\end{array}$ & Material recuperation \\
\hline
\end{tabular}

16

17

18
Interim-use

Public investment

support

Recognition of regional

differences

Land reclamation

Pilot projects

Flexible valorization

routes
Regional waste Econ., Env.,

agency

Soc.

Local to regional

SU, RU, EU, $\mathrm{MU}$

Econ., Soc. Local to supranational SU, RU

Industrial actors

Econ., Env.,

Soc.

Local to regional

$S U, R U, E U$

Industrial actors

and local

government

Institutional and Econ., Env.,

industrial actors Soc.

$\begin{array}{ll}\text { Econ., Env., } & \text { Regional to } \\ \text { Soc. } & \text { supranational }\end{array}$

$\mathrm{MU}$

\section{European}

government and

operators

Institutional

actors and

operators

Econ., Soc. Local

$\mathrm{MU}, \mathrm{SU}$

Econ., Env.,

Soc.

Local to regional

EU, MU

TU, MU

Global

T

operators

Operators

$\begin{array}{lll}\text { Econ., Soc. } & \text { Local to supranational } & \text { MU. TU } \\ \text { Econ., Env., } & \text { Local to regional } & \text { MU, TU, EU } \\ \text { Soc. } & \end{array}$




\subsection{Societal Needs}

88 Five stakeholder needs mainly affect public acceptance, and are thus considered societal needs.

89 In this context, public acceptance is defined as approval of an ELFM project by public stakeholders,

90 i.e. institutional and community actors. Interestingly, all needs are considered to influence ELFM

91 implementation on a local or local to regional level and are expressed by either local community

92 members or multiple stakeholder classes including local community members. The needs

93 perceived solely by local community members are protection against disamenities, (1) and

94 creation of employment (2).

95 The first stakeholder need (1) is expressed through the expectation of citizens to experience discomfort through noise, odor, dust or increased traffic coming from ELFM operations. While

97 societal effects might be quite obvious by increasing public acceptance and the well-being of 98 citizens, economic and environmental effects are also implied. Changing transport routes or 99 means (e.g. from road to rail), for example, can influence environmental emissions of an ELFM 100 project as well as private costs. Local community members and operators are mainly affected, 101 defining the range of effects to be local to regional.

102 The need for creation of employment (2) could also be categorized in relation to techno-

103 economic needs. Nevertheless, being expressed by local community members and aiming 104 towards societal benefits of local and regional growing labor markets, it was considered to mainly 105 affect public acceptance. The essence of this need is its effects on the societal and economic costs 106 and benefits. While an increase in employment increases public acceptance and could generate 107 economic growth through secondary income effects, it also raises private costs at a project level. 
108 Effects of creating employment mostly affect local community members and reach out locally to 109 regionally, albeit ELFM implementation at an industrial scope could affect economic growth on a 110 federal or even supranational level.

111 The next three stakeholder needs were expressed by multiple actors (c.f. Table 2) and include 112 communal benefits (3), stakeholder involvement (4), and safety (5). Need 3 exceeds relative 113 benefits through lessened disamenities or increased employment and can include monetary and 114 non-monetary benefits like the creation of public recreational land, communal engagement, 115 financial compensations or increased property prices depending on the after-use of the 116 excavated landfill. Creating such benefits can lead to public and private costs and benefits. As the 117 name of this need already suggests, impacts are considered to reach local to regional levels, 118 affecting mostly local communities and governments.

119 Stakeholder involvement (4) is being perceived as one of the biggest societal challenges by all 120 participants. Operators are not only motivated to distribute knowledge and information in order 121 to increase public acceptance but also to promote ELFM to investors. This need affects societal 122 and economic factors through the generation of private and public costs for information material, 123 lobbying or the use of public infrastructure. It goes beyond the project level, including actors 124 along the value chain and international organizations, impacting at local to global levels.

125 The need for safety (5) is perceived with various notions depending on the stakeholder class. 126 Operators expressed concerns for the safety of workers, while community members referred the 127 concept to socio-environmental risks like groundwater contamination or the reintroduction of 128 toxic substances into material circles. The scientific actor perceived a safety risk for a lack of 
129 control mechanisms of already in-place regulations. A lack of safety mechanisms can lead to

130 environmental damages as well as public and private costs. While this need could be further 131 differentiated into environmental safety and workers' safety, for example, it essentially

132 originates in ELFM operations and is expressed by all stakeholder classes. Therefore, all safety 133 issues are summarized under this need.

\section{$134 \quad 4.2$ Environmental Needs}

135 All stakeholders perceived a general need for ELFM being environmentally beneficial.

136 Nonetheless, environmental needs were mainly expressed by institutional actors (c.f. Table 2).

137 These needs included the need for avoided impacts (6), the reduction of long-term systematic 138 environmental risks (7), and landfill conversion (8).

139 General environmental benefits of ELFM are expected to mainly be achieved through the 140 mitigation of primary resource consumption and long-term landfill impacts. Need 6 has a local to 141 global range and primarily refers to environmental and societal issues.

142 Reducing long-term systematic risks (7) aims to prevent future, unforeseen environmental 143 impacts due to climatic changes at a systematic level. Through changes in precipitation, for 144 example, risks concerning groundwater contamination also change. If certain regions are 145 exposed to higher flood risks in the future, mining landfills within these regions would reduce the 146 systematic risk for groundwater contamination in that region (c.f. Wille, 2018). The mitigation of 147 risks alike could imply public and private costs for preventive measures, making this a three148 dimensional need. 
149 The need for landfill conversion (8) was expressed by the regional waste agency Its 150 implementation targets the remediation of natural habitat, especially the soil, after waste 151 removal. Hence, it is perceived as an environmental benefit and almost naturally part of ELFM.

152 Actual impacts, however, depend on the land use after remediation. Depending on many factors 153 like waste composition, location, ownership or the after-use, meeting this need could imply 154 additional private or public costs and benefits. It can be expected that impacts are mainly local 155 to regional.

1564.3 Regulatory needs

157 Social and environmental needs are to some extent introduced to other stakeholders by the local 158 communities. The need for regulatory changes (9), on the other hand, was mentioned by all 159 stakeholder classes but local community members. Especially the regional waste agency as well 160 as industrial actors perceived a need for legislation on ELFM. The regional waste agency 161 specifically expressed a need for the interim-use of closed landfills (10) that could be mined in 162 the future and ELFM's integration into European policy frameworks. Industrial actors stated the 163 need for public investment support (11) and the consideration of regional differences when 164 implementing regulations (12).

165 Despite the impression that no current legislation is hindering ELFM implementation, industrial 166 and scientific actors, and regional institutions would appreciate a defining legal framework. 167 Regulatory changes imply a societal cost but can at the same time lead to changes in private cost 168 structures and environmental impacts. This is essentially true for all regulatory needs but the 169 need for investment support (11). While investment support in form of green certificates, for 
170 example, could lead to environmental impacts at a regional to global level as more emissions are

171 produced, at a project level, these effects can be neglected.

172 The interim-use of closed landfills (10) could be part of ELFM regulation and is also a three173 dimensional need. It would comprise the period after closure of a landfill and before mining 174 operations begin. Effects of meeting this need highly depend on its implementation but would 175 range from local to regional levels. Potential private and societal costs and benefits, as well as 176 environmental changes, are implied when installing a solar plant at a closed landfill site, for 177 instance.

178 The need for public investment support (11) was mentioned by all industrial actors unilaterally. 179 Integrating this need into ELFM regulation could take the form of tax reliefs, subsidies or public180 private partnerships. This need can potentially reach out from local communities to 181 supranational institutions. Private economic benefits and societal costs are implied.

182 In the context of ELFM regulation, technology providers urged for the recognition of local and 183 regional differences (12). This should not only take socio-economic structures into account, like 184 population densities, but also environmental variation in soil and climatic conditions. Depending 185 on these differences, variations in safety regulations or the interim-use could be optimized and 186 implemented. Investment support could also vary over different regions, taking industrial 187 symbiosis opportunities into account, for example, and relating this need to the needs 5, 10 and 188 11. Naturally, this need takes effect at a local and regional level. 


\subsection{Techno-economic needs}

Economic and technological needs are combined to techno-economic needs because they are so closely related in ELFM implementation. Technological development plays a crucial role in the profitability of ELFM projects. Regarding WtM and WtE technology, most ELFM projects in the past were conducted at lab or pilot scale (c.f. Section 2.1). Improving efficiencies and pushing innovation towards a circular economy will affect societal, economic and environmental issues. Multiple stakeholders (c.f. Table 2) stated more general needs for economic growth (13), technological development (14), as well as material valorization (15), and land reclamation (16). Industrial actors expressed three additional needs: the installation of ELFM pilot projects at industrial scale to push implementation (17) and flexibility in ELFM valorization routes (18).

At a project level, the effects of economic development (13) are more likely to have a local to regional range, while technological development (14) is more likely to reach out further. The economic development highly depends on market developments that can affect private cost and benefits through rising salaries and revenues, for example. Rising salaries, on the other hand, generate secondary income effects that can have a notable impact at local levels. In contrast, technological development also has societal costs and benefits that can include research funding or risk reduction through environmental improvements. Moreover, technological development heavily influences the choice of valorization route for ELFM projects, which again is also dependent on market developments. Industrial actors are mainly motivated to push technological development to improve profitability, whereas institutional actors also stated potential (geo)strategic advantages. 
210 The need for material recuperation (15) was expressed by the European governmental actor and

211 the operators. Mainly construction materials are considered in this context, as the share of

212 metals is usually rather small and the fine fraction, containing mainly biomass and plastics, is

213 difficult to recycle (c.f. Section 2.1). The European Union, being also a well-established producer

214 of construction materials, would further increase its resource independence. Impacts would

215 reach from a local to regional level as the economic feasibility of transport ranges for construction

216 materials is limited. Furthermore, this need is closely related to avoided impacts (6) and

217 technological advances (15) could potentially yield environmental benefits.

218 Land reclamation (16) plays an important role for institutional actors as well as operators.

219 Impacts on sustainability highly depend on the after-use, but potential effects are mainly limited

220 to a local level. Societal costs and benefits can be monetary and non-monetary: changes in

221 housing prices or health improvements through the creation of recreational land, for example.

222 This need is closely related to Need 8.

223 The need for ELFM pilot-scale projects for proof of principle (17) was expressed by the operators.

224 It implies societal costs through the participation of public research, but also creates private costs

225 for research and development at relatively high economic risks. The operators further expect to

226 use these pilot projects as vehicles for knowledge distribution to push general ELFM

227 implementation. The range of effects of this stakeholder need is therefore considered local to 228 supranational.

229 The need for flexibility in valorization routes (18), also expressed by the operators, is perceived 230 as a measure to react to short- and mid-term market developments. It also challenges 
231 technological development and research to take these flexible valorization routes into account.

232 Effects manifest mainly at local to regional levels and impacts are mainly economic and 233 environmental.

$234 \quad 4.5$ Uncertainty

235 The following section treats the five types of uncertainty. Complying with stakeholder needs 236 should generally lower uncertainty about ELFM. Nonetheless, the implementation of some 237 stakeholder needs could also have increasing effects. Figures 4 to 8 show how the different needs 238 affect the five types of uncertainty, arranged by the four categories. The direction of effects can 239 be positive $(+)$, meaning an increase in uncertainty, negative (-), i.e. a decrease in uncertainty or $240(+/-)$ unclear, depending on contextual factors. 


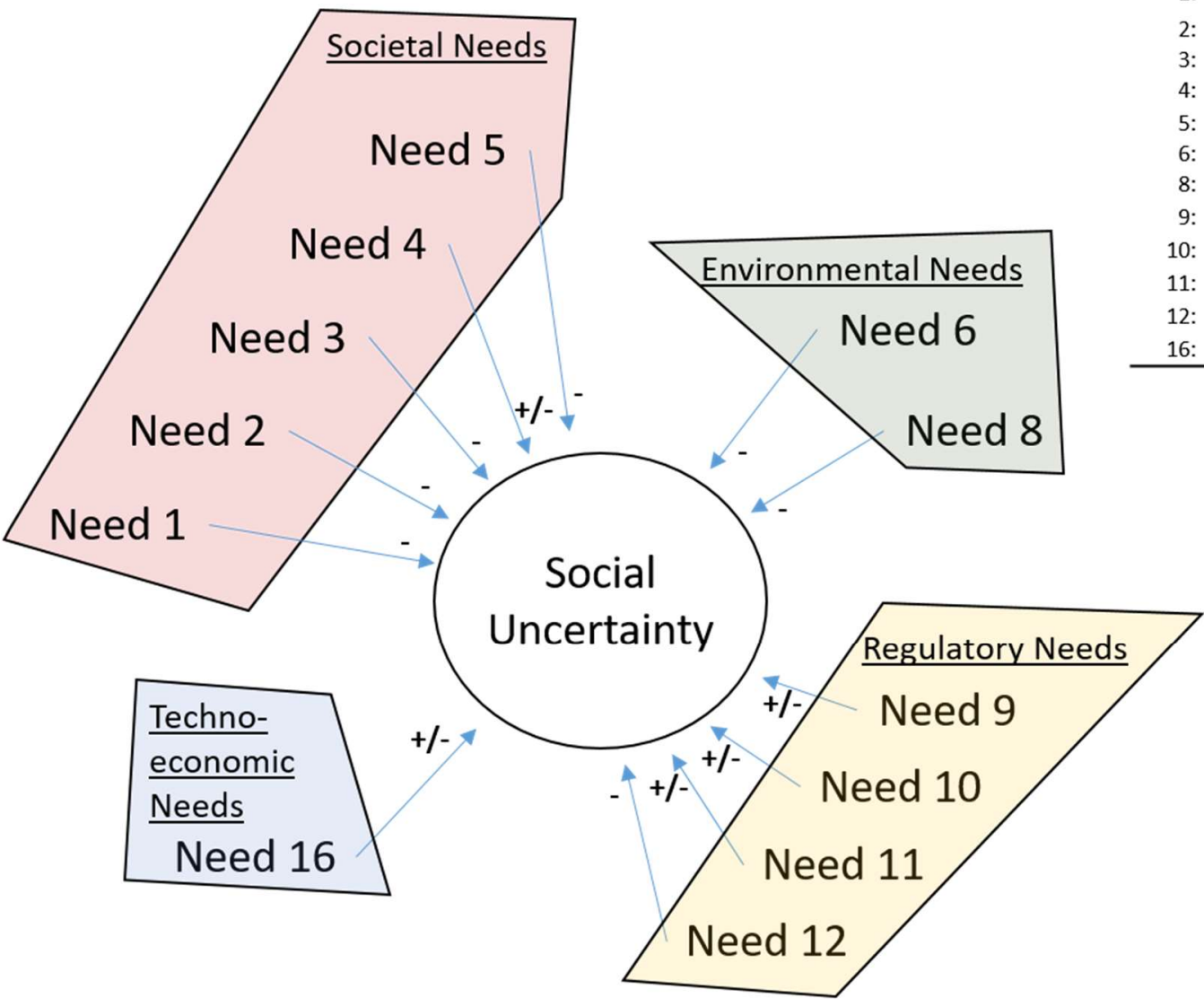

\begin{aligned} & Need Name \\ & \hline 1: Protection against disamenities \\ & 2: Employment \\ & 3: Communal benefits \\ & 4: Stakeholder involvement \\ & 5: Safety \\ & 6: Avoided Impacts \\ & 8: Landfill conversion \\ & 9: Regulatory changes \\ & 10: Interim-use \\ & 11: Public investment support \\ & 12: Recognition of regional differences \\ & 16: Land reclamation \\ & \hline\end{aligned}

Figure 4: The interaction of stakeholder needs with social uncertainty.

243 Social uncertainty is generally expected to lower with the compliance of societal needs, and thus,

244 increase public acceptance. However, involving stakeholders (4) and increasing knowledge

245 distribution about ELFM could motivate ELFM supporters similarly as ELFM opposition and the

246 directional effects of this need on social uncertainty are unclear. Complying with environmental

247 needs is expected to lower social uncertainty because of the dominant role environmental

248 benefits from ELFM play for community and institutional actors. Through the implementation of

249 a regulatory framework for ELFM, certainty about processes and procedures could be created for

250 all stakeholders, preventing public and industrial fears and lowering social uncertainty in the long

251 run but social uncertainty could raise short-term, due to public discussions and legal procedures 
252 leading to the implementation of regulations. The only techno-economic need affecting social

253 uncertainty is land reclamation (16) but effects are unclear and highly depend on the after-use.

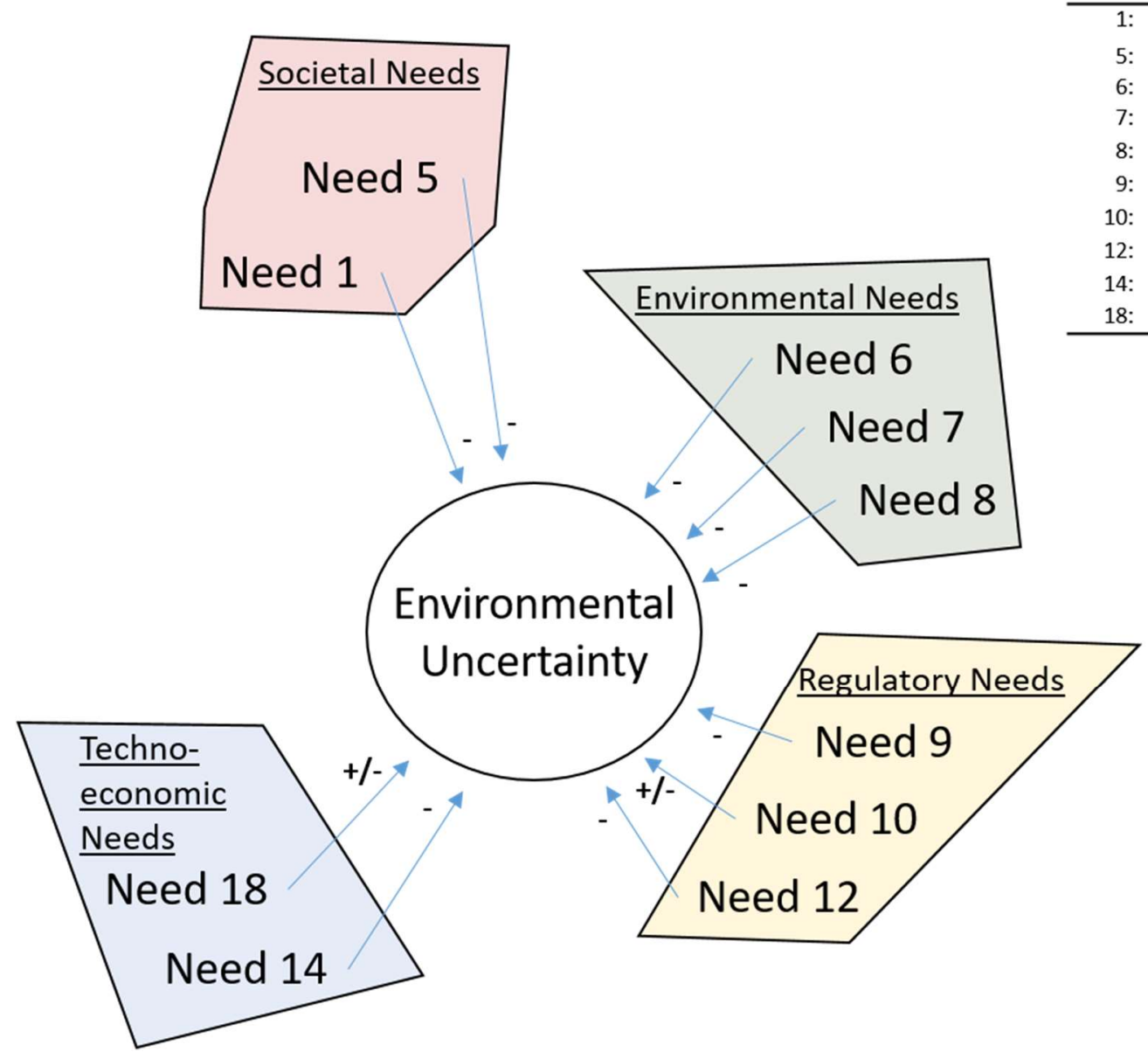

\begin{aligned} Need & Name \\ \hline 1: & Protection against disamenities \end{aligned}

5: Safety

Avoided Impacts

Mitigation of systematic risks

Landfill conversion

Regulatory changes

Interim-use

2: Recognition of regional differences

14: Technological development

18: Flexible valorization routes

Figure 5: The interaction of stakeholder needs with environmental uncertainty.

257 Environmental uncertainty is expected to lower with overall creating environmental benefits

258 through ELFM. Protecting community actors from disamenities (1) and increasing the safety of

259 ELFM operations (5) (e.g. handling of hazardous waste) should affect environmental uncertainty

260 similarly, as both needs are closely related to preventing emissions. Implementing a regulatory 
261 framework (9), taking regional differences into account (12) could further lower environmental

262 uncertainty in a similar way as social uncertainty. Integrating an interim-use phase into ELFM

263 regulation, however, could also create more environmental uncertainty, depending on its

264 implementation and time-dependent, dynamic effects. Material valorization (14) is closely linked

265 to avoided impacts, whereas flexible valorization routes (18) could potentially create

266 environmental risks and opportunity costs due to trade-off considerations with economic factors.

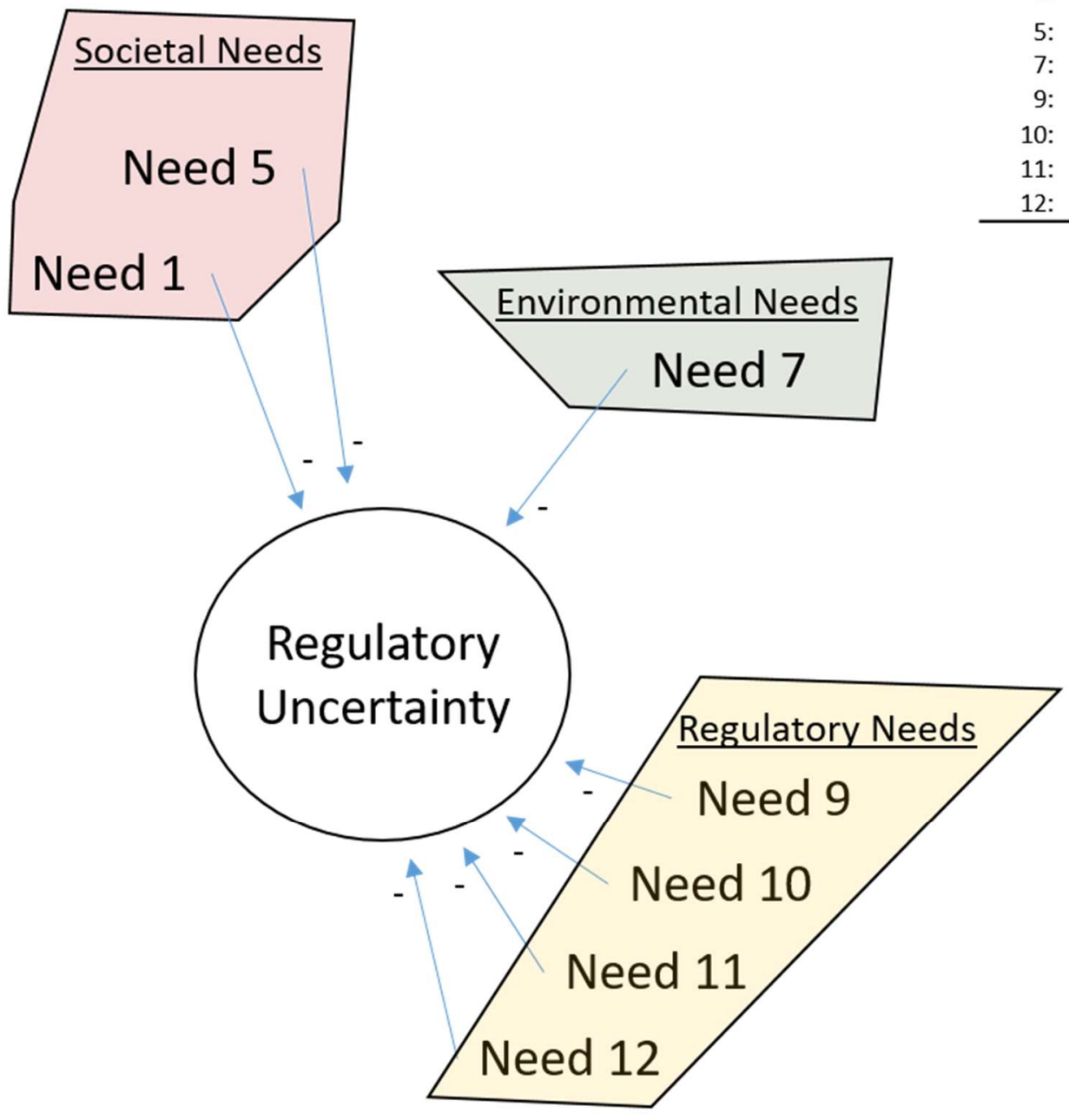

\begin{aligned} & Need Name \\ & \hline 1: Protection against disamenities \\ & 5: Safety \\ & 7: Mitigation of systematic risks \\ & 9: Regulatory changes \\ & 10: Interim-use \\ & 11: Public investment support \\ & 12: Recognition of regional differences \\ & \hline\end{aligned}

268 Figure 6: The interaction of stakeholder needs with regulatory uncertainty. 
269 Regulatory uncertainty should generally lower with the implementation of ELFM regulation (9-

270 12). The integration of community needs (1 and 5), to some extent, could additionally lower

271 regulatory uncertainty and increase public acceptance. Nonetheless, as no regulatory framework

272 exists, mitigating systematic risks (7) could increase uncertainty, even though generally ELFM is

273 compliant with current legislation (c.f. Section 2.3). Building infrastructure on top of a closed

274 landfill bares more risk if it is unclear if that landfill might have to be mined in the future due to

275 flood risks, for example. 


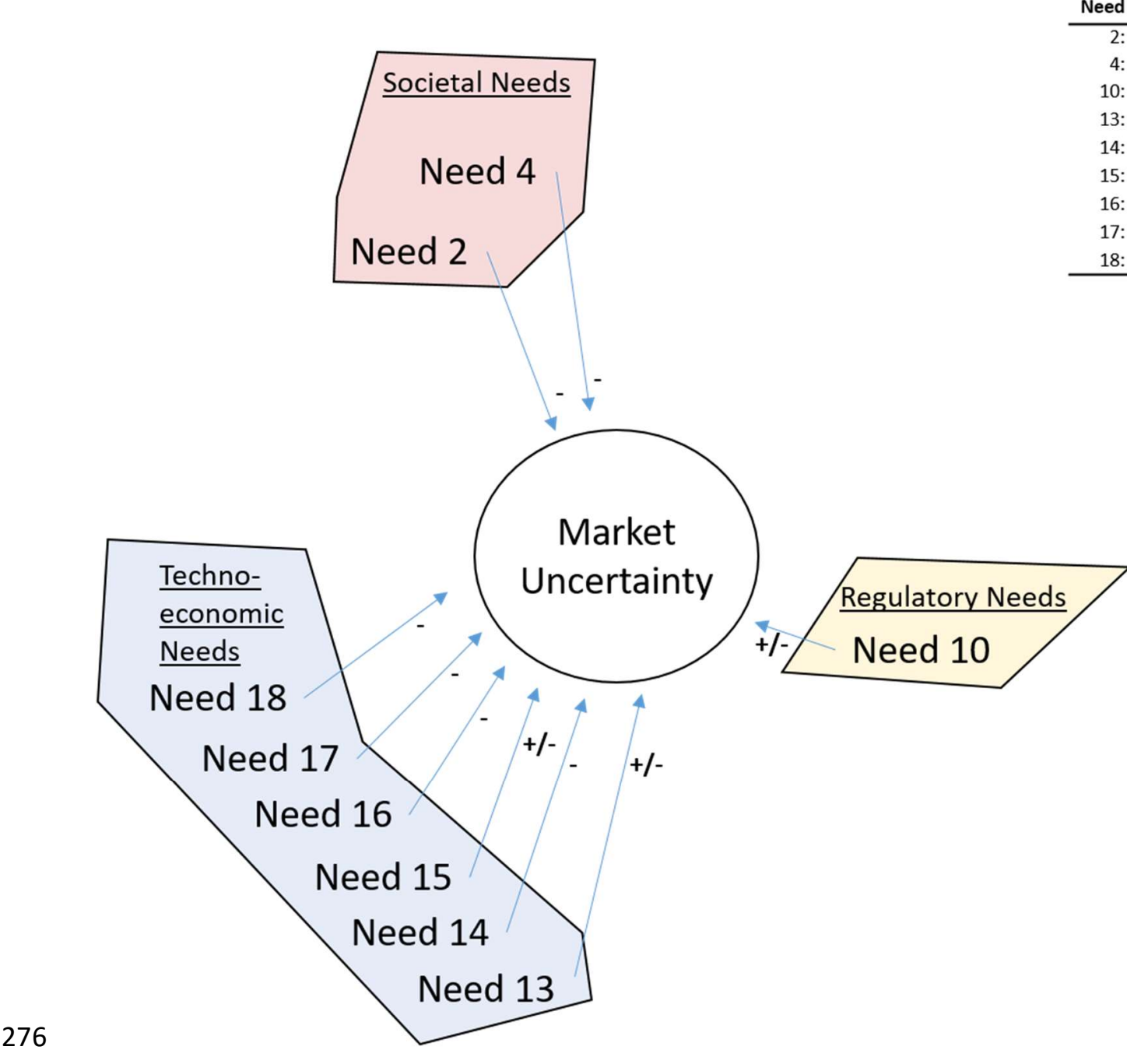

277 Figure 7: The interaction of stakeholder needs with market uncertainty.

278 Market Uncertainty is predominantly affected by techno-economic needs. While complying with

279 most of these needs should lower market uncertainty, economic growth (13) and technological

280 development (15), and with it, potential changes in the dynamics of markets, could also increase

281 uncertainty. Creating employment opportunities (2) is likely to interact with market uncertainty

282 through secondary income effects but effects are unclear. Integrating stakeholder, on the other

283 hand, should lower market uncertainty through the distribution of information to potential

284 investors and industrial actors. Integrating an interim-use phase (10) would also interplay with 
285 market uncertainty since the optimal time to mine a landfill depends on the marketability of an

286 ELFM project's products.

\begin{aligned} & Need Name \\ & \hline 15: Material recuperation \\ & 17: Pilot projects \\ & 18: Flexible valorization routes \\ & \hline\end{aligned}

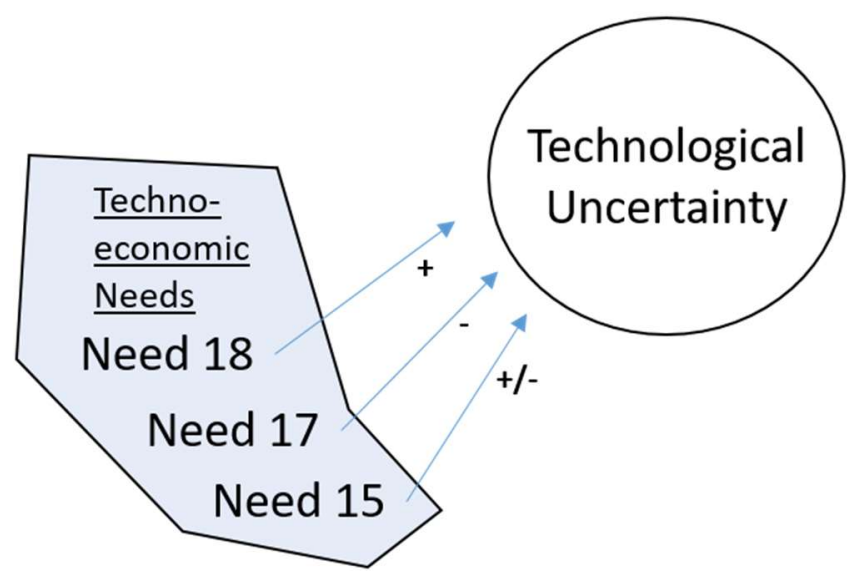

Figure 8: The interaction of stakeholder needs with technological uncertainty.

Technological uncertainty is the only type of uncertainty not affected by other needs than techno-economic ones. Naturally, technological development (15) is affecting uncertainty about also create barriers for the concept through the development of alternatives for ELFM products 293 and thus increasing competition. ELFM pilot projects (17) should reduce technological 294 uncertainty by creating more certainty about quality standards of ELFM products and increased 295 learning effects. Meeting the need for flexibility in ELFM valorization routes (18) makes plant and 
296 process development more challenging and more options would most likely increase 297 technological uncertainty.

300 Through a broad stakeholder integration, several stakeholder needs were identified and 301 analyzed. This anticipatory approach has shown different perspectives, as well as effects on ELFM 302 implementation and various stakeholder groups. The spatial distribution of the effects of ELFM 303 implementation highlights the potential for conflicts in public acceptance and should be 304 considered in future research. Moreover, research is needed to further structure ELFM related 305 uncertainties. Different types of uncertainties are present throughout all stakeholder need 306 categories, and half of all stakeholder needs, i.e. 9 out of 18, refer to all three dimensions of 307 sustainability. This emphasizes the need for an integrated assessment model and further method 308 development for ELFM.

309 While the integration of stakeholders, in practice, is well established for the Remo landfill (c.f. 310 Ballard et al., 2018), this is rarely reflected in the case-specific literature. Technological, 311 environmental and market uncertainties are analyzed to some extent by means of sensitivity 312 analyses (c.f. Section 2.2) but, similarly to suggestions from other ELFM studies, indicate that 313 more research is needed. Overall, an integrated assessment method is lacking, although 314 combined environmental and economic assessments (e.g. Danthurebandara et al., 2015) are 315 performed, and societal perspectives are, to some extent, integrated through the monetization 316 of (environmental) externalities or rankings (c.f. Section 2.1). Societal needs (e.g. Need 2 and 5), 
317 however, are rarely addressed. Need 1, protection against disamenities, is only addressed in the 318 context of biodiversity by installing noise mitigation facilities for the protection of wildlife (c.f. De 319 Vocht et al., 2011). Environmental needs are addressed. Avoided impacts (6), for example, are 320 considered in LCA and economic studies, but results vary due to different methodological choices

321 (c.f. Section 2.1). Techno-economic needs are better incorporated into ELFM research at Remo, 322 as regional economic potentials are assessed, and different valorization routes are reflected in 323 various ELFM scenarios (c.f. Section 2.1). It should be noted that, in contrast to the importance 324 given to it in the interviews, land reclamation (16) constitutes a relatively low economic benefit 325 for the Remo case (c.f. Van Passel et al., 2013) but can have a significant (positive) environmental 326 impact (c.f. Danthurebandara et al., 2015). Regulatory needs are also not reflected, although 327 considering public investment support (11), as well as an interim-use phase (10), would have a 328 noticeable influence on the scenario building, not only for the Remo case.

329 Generally, prioritizing environmental factors differently from economic or societal ones can lead 330 to changes in valorization routes, and thus affects scenario building. Costs related to public 331 acceptance (e.g. for lobbying) have to be taken into account, as well as non-monetary benefits 332 from the integration of stakeholder needs, like changes in uncertainties. Related factors could be 333 integrated into the building of scenarios, including legal costs in case of low acceptance due to 334 non-compliance with other factors like protection against disamenities (1). A more differentiated 335 scenario building would reduce social, regulatory and technological uncertainty, and, in 336 combination with the analysis of related costs and benefits, result in a clearer picture of 
337 possibilities for ELFM implementation, thus increasing the quality of decision support for ELFM 338 stakeholders.

339 Another important issue that has been neglected by ELFM research so far is that of time340 dependent factors. The need for flexibility of ELFM valorization routes (18), similarly to public 341 investment support (11), greatly depends on the consideration of market developments and 342 generates research and opportunity costs for achieving this flexibility. Is the area of a closed 343 landfill used for electricity generation through solar panels, for example, but planned ELFM 344 operations would focus on material valorization, then the optimal time to invest depends on the 345 development of electricity and material prices. Environmentally, negative impacts from ELFM 346 operations (c.f. Danthurebandara et al., 2015; Winterstetter et al., 2015) are contradicting the 347 relatively mild impacts of a "business as usual" or "do nothing" scenarios. However, ELFM's 348 contribution to the mitigation of long-term environmental risks of landfills through waste 349 removal plays an important role for stakeholders, although in reality these risks should be 350 evaluated case specifically, and the challenge of assessing this topic still has to be taken on by 351 ELFM research (Sauve and Van Acker, 2018), also depending on LFG emissions and their behavior 352 over long timeframes. Research in this area is needed to reduce environmental uncertainty. 353 Including dynamic modeling into ELFM assessment would further lower market-related 354 uncertainties and could be made possible through the combination of risk assessment with LCA, 355 for example, or the use of real options theory.

356 Integrating intra- and interdimensional relations and trade-offs in ELFM assessment is a difficult 357 task. Further analysis of the interaction between economic, environmental and societal factors 
358 is needed. Enhancing the flexibility of ELFM valorization routes (18), for example, could generate 359 environmental opportunity costs when considering trade-offs with the economic dimension. Due 360 to external factors (e.g. markets), a valorization route (WtE vs. WtM) could be chosen that 361 promotes a sub-optimal environmental performance but yields higher profits. These 362 environmental opportunity costs also imply societal impacts whose prevention often implies 363 private economic costs. Often, monetization, as a form of normalization of impacts, is used to 364 resolve these trade-off dilemmas. However, to actually compare non-monetary impacts on the 365 basis of scenarios, monetization is not immediately necessary. Rankings can be created and 366 qualitative research can help to determine priorities, underlining the importance of stakeholder 367 integration and the development of an anticipatory approach. A beneficial side effect of more 368 qualitative research in the field of ELFM would be knowledge accumulation and with it the 369 reduction of social uncertainty.

370 Another challenge in assessing ELFM comes to light considering the distribution of societal 371 impacts. While an ELFM project can have an overall socio-environmental benefit through the 372 reduction of global GHG emissions, local emissions (e.g. particulate matter) might increase due 373 to ELFM operations. This can imply monetary and non-monetary costs in one location whereas 374 non-monetary benefits are usually generated at another location. The integration of these 375 different spatial distributions into ELFM research is not an easy task and deserves more scientific 376 attention. This would lead to a more granular differentiation of ELFM impacts and contribute to 377 a sensible ELFM implementation. It could further lead to a reduction in social and regulatory 378 uncertainty and a mix of qualitative and quantitative research methods is necessary. 
3796 Conclusions

380 Conducting stakeholder interviews has proven to be a valid method to evaluate stakeholder

381 needs. Although some stakeholder needs have been addressed in the assessment of the Remo

382 case, the study shows that an integrated assessment method is needed, and implications for

383 ELFM research can be generalized even though specific stakeholder needs might vary amongst

384 different case studies.

385 The anticipatory approach has uncovered several research gaps and important factors affecting 386 ELFM implementation. Numerous parameters, affecting the assessment of different 387 sustainability dimensions in ELFM, were derived. However, more integrated research is needed 388 to ensure that results are complete and sound. The stakeholder needs were categorized into 389 societal needs, environmental needs, regulatory needs, and techno-economic needs. Societal 390 and techno-economic needs dominate in absolute numbers but the interviews revealed that 391 depending on the stakeholder class, a different emphasis is given to the three sustainability 392 dimensions and environmental needs are perceived as highly important by institutional and 393 community actors.

394 It is important to note that private economic structures of ELFM projects are affected through 395 the integration of these stakeholder needs, and time and market dependent variables should be 396 considered in the future. Furthermore, more attention should be given to the scenario building 397 in ELFM assessment. ELFM assessment has to find a way of dealing with inter-dimensional trade398 offs. This includes the assessment of economic and environmental opportunity costs when 399 comparing different scenarios or assessing the combination of different valorization routes. 
To further foster the societal assessment of ELFM projects an integrated method is needed. Next steps should include the following: (i) refine economic and environmental assessment methods, (ii) closely analyze socio-economic costs and benefits of ELFM, (iii) find indicators for societal impacts and (iv) integrate the distribution of impacts into ELFM assessment together with ELFM stakeholders.

\section{Acknowledgments}

This project has received funding from the European Union's EU Framework Programme for Research and Innovation Horizon 2020 under Grant Agreement No 721185.

Part of the research was presented at the 4th International Symposium on Enhanced Landfill Mining 2018 in Mechelen, Belgium.

The authors would like to thank all interviewees for their participation and openness.

\section{References}

Arnkil, R., Järvensivu, A., Koski, P., Piirainen, T., 2010. Exploring Quadruple Helix: Outlining user-oriented innovation models, Tampere: The CLIQ.

Ballard, M., Becherer, J., Coeymans, K., De Block, E., De Bruyn, G., De Coster, L., De Schutter, J., Lemmens, J., Philipsen, L., Schroeyers, F., TIMMERS, H., VANDEBEEK, G., VANHEMEL, P., VANNUFFELEN, G., 2018. A Locals' Perspective Towards Social Acceptance of the Closing-the-circle Project in Houthalen-Helchteren, in: 4th International Symposium on Enhanced Landfill Mining. pp. 353-358.

Behets, T., Umans, L., Wille, E., Bal, N., Van Den, P., 2013. Landfill Mining in Flanders : Methodology for Prioritization. OVAM.

Bobe, C., Van De Vijver, E., 2019. Offset errors in probabilistic inversion of small-loop frequency-domain electromagnetic data: a synthetic study on their influence on magnetic susceptibility estimation. Int. Work. Gravity, Electr. Magn. Methods Their Appl. 1-10.

Bosmans, A., Vanderreydt, I., Geysen, D., Helsen, L., 2013. The crucial role of Waste-to-Energy technologies in enhanced landfill mining: A technology review. J. Clean. Prod., Special Volume: Urban and Landfill Mining 55, 10-23. https://doi.org/10.1016/j.jclepro.2012.05.032

Bryson, J.M., 2004. What to do when Stakeholders matter. Public Manag. Rev. 6, 21-53. 
Burlakovs, J., Jani, Y., Kriipsalu, M., Vincevica-Gaile, Z., Kaczala, F., Celma, G., Ozola, R., Rozina, L., Rudovica, V., Hogland, M., Viksna, A., Pehme, K.M., Hogland, W., Klavins, M., 2018. On the way to 'zero waste' management: Recovery potential of elements, including rare earth elements, from fine fraction of waste. J. Clean. Prod. 186, 81-90. https://doi.org/10.1016/j.jclepro.2018.03.102

Council Directive, 2008. Council directive 2008/98/EC on waste framework, Official Journal of the European Communities.

Council Directive, 1999. Council Directive 1999/31/EC on the landfill. Off. J. Eur. Communities L182/1-19. https://doi.org/10.1039/ap9842100196

Cucurachi, S., Van Der Giesen, C., Guinée, J., 2018. Ex-ante LCA of Emerging Technologies. Procedia CIRP 69, 463-468. https://doi.org/10.1016/j.procir.2017.11.005

Damigos, D., Menegaki, M., Kaliampakos, D., 2015. Monetizing the social benefits of landfill mining: Evidence from a Contingent Valuation survey in a rural area in Greece. Waste Manag. 51, 119-129. https://doi.org/10.1016/j.wasman.2015.12.012

Danthurebandara, M., Passel, S.V.A.N., Van Acker, K., 2013. Life Cycle Analysis of Enhanced Landfill Mining : Case Study for the Remo Landfill 1-23. https://doi.org/10.13140/RG.2.1.4576.9763

Danthurebandara, M., Van Passel, S., Machiels, L., Van Acker, K., 2015a. Valorization of thermal treatment residues in Enhanced Landfill Mining: environmental and economic evaluation. J. Clean. Prod. 99, 275-285. https://doi.org/10.1016/j.jclepro.2015.03.021

Danthurebandara, M., Van Passel, S., Van Acker, K., 2015b. Environmental and economic assessment of 'open waste dump' mining in Sri Lanka. Resour. Conserv. Recycl. 102, 67-79. https://doi.org/10.1016/j.resconrec.2015.07.004

Danthurebandara, M., Van Passel, S., Vanderreydt, I., Van Acker, K., 2015c. Assessment of environmental and economic feasibility of Enhanced Landfill Mining. Waste Manag., Urban Mining 45, 434-447. https://doi.org/10.1016/j.wasman.2015.01.041

De Vocht, P., Descamps, S., De Vocht, A.J.P., Descamps, S., 2011. Biodiversity and Enhanced Landfill Mining : Weighting local and global impacts? Int. Acad. Symp. Enhanc. Landfill Min. 275-290. https://doi.org/10.13140/2.1.4969.8245

Eisenberger, M., 2015. Gutachten über sich ergebende Rechtsfragen zum Projekt LAMIS-Landfill Mining Österreich-Pilotregion Steiermark. Graz.

Frändegård, P., Krook, J., Svensson, N., 2015. Integrating remediation and resource recovery: On the economic conditions of landfill mining. Waste Manag. 42, 137-147. https://doi.org/10.1016/j.wasman.2015.04.008

Frändegård, P., Krook, J., Svensson, N., Eklund, M., 2013a. A novel approach for environmental evaluation of landfill mining. J. Clean. Prod., Special Volume: Urban and Landfill Mining 55, 24-34. https://doi.org/10.1016/j.jclepro.2012.05.045

Frändegård, P., Krook, J., Svensson, N., Eklund, M., 2013b. Resource and Climate Implications of Landfill Mining. J. Ind. Ecol. 17, n/a-n/a. https://doi.org/10.1111/jiec.12039 
485

486

487

488

489

490

491

492

493

494

495

496

497

Garcia Lopez, C., Hernández Parrodi, J.C., Küppers, B., Clausen, A., Pretz, T., 2018. No TitleThe potential of the ballistic separator type STT6000 as a first step for the recovery of refuse derived fuel from landfill material: A case study at Mont Saint Guibert Landfill (Belgium), in: Tom Jones, P., Machiels, L. (Eds.), 4th International Symposium on Enhanced Landfill Mining. Mechelen, pp. 113-120.

Geysen, D., 2017. Enhanced Landfill Mining am Beispiel der Deponie Remo in Belgien. Resour. Abfall, Rohstoff, Energ. 30, 515-535.

Goodman, L.A., 1961. Snowball Sampling. Ann. Math. Stat. 32, 148-170. https://doi.org/10.1214/aoms/1177705148

Group Machiels, 2018. Closing the Circle Project [WWW Document]. URL https://machiels.com/en/division/europe/environmental-services/closing-the-circle-project/ (accessed 7.22.18).

Gusca, J., Fainzilbergs, M., Muizniece, I., 2015. Life Cycle Assessment of Landfill Mining Project. Energy Procedia, International Scientific Conference "Environmental and Climate Technologies, CONECT 2014 72, 322-328. https://doi.org/10.1016/j.egypro.2015.06.047

Heckathorn, D.D., 1997. Respondent-Driven Sampling: A New Approach to the Study of Hidden Populations. Soc. Probl. 44, 174-199. https://doi.org/10.2307/3096941

Hermann, R., Baumgartner, R.J., Vorbach, S., Ragossnig, A., Pomberger, R., 2015. Evaluation and selection of decision-making methods to assess landfill mining projects. Waste Manag. Res. 33, 822-832. https://doi.org/10.1177/0734242X15588586

Hermann, R., Baumgartner, R.J., Vorbach, S., Wolfsberger, T., Ragossnig, A., Pomberger, R., 2016a. Holistic assessment of a landfill mining pilot project in Austria: Methodology and application. Waste Manag. Res. 34, 646-657. https://doi.org/10.1177/0734242X16644517

Hermann, R., Wolfsberger, T., Pomberger, R., Sarc, R., 2016b. Landfill mining: Developing a comprehensive assessment method. Waste Manag. Res. 34, 1157-1163. https://doi.org/10.1177/0734242X16657610

Hernández Parrodi, J.C., Höllen, D., Pomberger, R., 2018. Potential and Main Technological Challenges for Material and Energy Recovery From Fine Fractions of Landfill Mining: a Critical Review. Detritus In Press, 1. https://doi.org/10.31025/2611-4135/2018.13689

Hoffnmann, V.H., Trautmann, T., Hamprecht, J., 2009. Regulatory Uncertainty : A Reason to Postpone Investments ? Not Necessarily Volker H . Hoffmann, Thomas Trautmann and. J. Manag. Stud. 46, 1227-1253. https://doi.org/10.1111/j.1467-6486.2009.00866.x

Hölzle, I., 2019. Analysing material flows of landfill mining in a regional context. J. Clean. Prod. 207, 317328. https://doi.org/10.1016/j.jclepro.2018.10.002

Jain, P., Powell, J.T., Smith, J.L., Townsend, T.G., Tolaymat, T., 2014. Life-Cycle Inventory and Impact Evaluation of Mining Municipal Solid Waste Landfills. Environ. Sci. Technol. 48, 2920-2927. https://doi.org/10.1021/es404382s

Johansson, N., Krook, J., Eklund, M., 2012. Transforming dumps into gold mines. Experiences from Swedish case studies. Environ. Innov. Soc. Transitions 5, 33-48. https://doi.org/10.1016/j.eist.2012.10.004 
Johansson, N., Krook, J., Frändegård, P., 2017. A new dawn for buried garbage? An investigation of the marketability of previously disposed shredder waste. Waste Manag. 60, 417-427. https://doi.org/10.1016/j.wasman.2016.05.015

Jones, P.T., Geysen, D., Tielemans, Y., Van Passel, S., Pontikes, Y., Blanpain, B., Quaghebeur, M., Hoekstra, N., 2013. Enhanced Landfill Mining in view of multiple resource recovery: a critical review. J. Clean. Prod., Special Volume: Urban and Landfill Mining 55, 45-55. https://doi.org/10.1016/j.jclepro.2012.05.021

Jones, P.T., Wille, J.E., Krook, J., 2018. 2nd ELFM Seminar in the European Parliament: 5 Lessons Learned Why we need to develop a broad Dynamic Landfill Management strategy and vision for Europe's 500,000 landfills. Policy Brief, EU Training Network for Resource Recovery through Enhanced Landfill 1-12.

Kieckhäfer, K., Breitenstein, A., Spengler, T.S., 2017. Material flow-based economic assessment of landfill mining processes. Waste Manag., Special Thematic Issue: Urban Mining and Circular Economy 60, 748-764. https://doi.org/10.1016/j.wasman.2016.06.012

Kolehmainen, J., Irvine, J., Stewart, L., Karacsonyi, Z., Szabó, T., Alarinta, J., Norberg, A., 2016. Quadruple Helix, Innovation and the Knowledge-Based Development: Lessons from Remote, Rural and LessFavoured Regions. J. Knowl. Econ. 7, 23-42. https://doi.org/10.1007/s13132-015-0289-9

Krook, J., Jones, P.T., Van Passel, S., 2018a. Why Enhanced Landfill Mining (ELFM) needs to be politically acknowledged to facilitate sustainable management of European landfills. Policy Brief, EU Training Network for Resource Recovery through Enhanced Landfill Mining (NEW-MINE).

Krook, J., Svensson, N., Eklund, M., 2012. Landfill mining: A critical review of two decades of research. Waste Manag. 32, 513-520. https://doi.org/10.1016/j.wasman.2011.10.015

Krook, J., Svensson, N., Van Acker, K., Van Passel, S., 2018b. How to Evaluate (Enhanced) Landfill Mining: A Critical Review of REcent Environmental and Economic Assessments, in: Jones, P.T., Machiels, L. (Eds.), 4th International Symposium on Enhanced Landfill Mining. Mechelen, pp. 317-332.

Laner, D., Cencic, O., Svensson, N., Krook, J., 2016. Quantitative Analysis of Critical Factors for the Climate Impact of Landfill Mining. Environ. Sci. Technol. 50, 6882-6891. https://doi.org/10.1021/acs.est.6b01275

Marella, G., Raga, R., 2014. Use of the Contingent Valuation Method in the assessment of a landfill mining project. Waste Manag. 34, 1199-1205. https://doi.org/10.1016/j.wasman.2014.03.018

Pastre, G., Griffiths, Z., Val, J., Tasiu, A.M., Camacho-Dominguez, E.V., Wagland, S., Coulon, F., 2018. A Decision Support Tool for Enhanced Landfill Mining. Detritus 01, 91-101. https://doi.org/10.26403/detritus/2018.5

Prell, C., Hubacek, K., Quinn, C., Reed, M., 2008. “Who's in the network?” When stakeholders influence data analysis. Syst. Pract. Action Res. 21, 443-458. https://doi.org/10.1007/s11213-008-9105-9

Quaghebeur, M., Laenen, B., Geysen, D., Nielsen, P., Pontikes, Y., Van Gerven, T., Spooren, J., 2013. Characterization of landfilled materials: screening of the enhanced landfill mining potential. J. Clean. Prod., Special Volume: Urban and Landfill Mining 55, 72-83. https://doi.org/10.1016/j.jclepro.2012.06.012 
Refsgaard, J.C., van der Sluijs, J.P., Højberg, A.L., Vanrolleghem, P.A., 2007. Uncertainty in the environmental modelling process - A framework and guidance. Environ. Model. Softw. 22, 15431556. https://doi.org/10.1016/j.envsoft.2007.02.004

Sauve, G., Van Acker, K., 2018. To Mine or not to Mine: A Review of the Effects of Waste Composition, Time and Long-Term Impacts of Landfills in the Decision Making for ELFM, in: Machiels, L., Jones, P.T. (Eds.), 4 Th International Symposium on Enhanced Landfill Mining. Mechelen, pp. 379-385.

Seidl, R., Lexer, M.J., 2013. Forest management under climatic and social uncertainty: Trade-offs between reducing climate change impacts and fostering adaptive capacity. J. Environ. Manage. 114, 461-469. https://doi.org/10.1016/j.jenvman.2012.09.028

Stemler, S., 2003. An Overview of Content Analysis. Mark. Rev. 3, 479-498. https://doi.org/10.1362/146934703771910080

Thomas, D.R., 2006. A General Inductive Approach for Analyzing Qualitative Evaluation Data. Am. J. Eval. 27, 237-246. https://doi.org/10.1177/1098214005283748

van der Zee, D.J., Achterkamp, M.C., de Visser, B.J., 2004. Assessing the market opportunities of landfill mining. Waste Manag. 24, 795-804. https://doi.org/10.1016/j.wasman.2004.05.004

Van Passel, S., Dubois, M., Eyckmans, J., de Gheldere, S., Ang, F., Tom Jones, P., Van Acker, K., 2013. The economics of enhanced landfill mining: Private and societal performance drivers. J. Clean. Prod., Special Volume: Urban and Landfill Mining 55, 92-102. https://doi.org/10.1016/j.jclepro.2012.03.024

Wagner, T.P., Raymond, T., 2015. Landfill mining: Case study of a successful metals recovery project. Waste Manag., Urban Mining 45, 448-457. https://doi.org/10.1016/j.wasman.2015.06.034

Wender, B.A., Foley, R.W., Hottle, T.A., Sadowski, J., Prado-Lopez, V., Eisenberg, D.A., Laurin, L., Seager, T.P., 2014. Anticipatory life-cycle assessment for responsible research and innovation. J. Responsible Innov. 1, 200-207. https://doi.org/10.1080/23299460.2014.920121

Wille, E., 2018. Flooding Risks at old Landfill Sites: Linear Economy Meets Climate Change, in: Jones, P.T., Machiels, L. (Eds.), Proceedings of the 4th International Symposium on Enhanced Landfill Mining. Mechelen, pp. 361-365.

Wille, E., 2016. Sustainable stock management and landfills : introduction to Enhanced Landfill Management \& Mining ( ELFM $^{2}$ ). Introduction to the policy framework in Flanders, in: Proceedings of the Third Academic International Symposium on Enhanced Landfill Mining. Lisbon.

Winterstetter, A., Laner, D., Rechberger, H., Fellner, J., 2015. Framework for the evaluation of anthropogenic resources: A landfill mining case study - Resource or reserve? Resour. Conserv. Recycl. 96, 19-30. https://doi.org/10.1016/j.resconrec.2015.01.004

Winterstetter, A., Wille, E., Nagels, P., Fellner, J., 2018. Decision making guidelines for mining historic landfill sites in Flanders. Waste Manag. 77, 225-237. https://doi.org/10.1016/j.wasman.2018.03.049

Zhou, C., Gong, Z., Hu, J., Cao, A., Liang, H., 2015. A cost-benefit analysis of landfill mining and material recycling in China. Waste Manag. 35, 191-198. https://doi.org/10.1016/j.wasman.2014.09.029 
584 The appendix shows the main questions developed for the interview guide. Due to limitations

585 in time and slightly different foci of each semi-structured interview, not all interviewees were 586 asked all of the questions and follow-up questions varied, depending on the given answers.

587 1. What is a landfill to you?

588 2. Can you, in general, describe what advantages and/or disadvantages having landfills $589 \quad$ comes with?

590 3. When you think about the REMO site, do you have positive or negative associations?

591 4. Are you familiar with the concept of LFM/ELFM?

$592 \quad 5$. Do you think LFM/ELFM should be done?

593 6. What projects about LFM/ELFM are you involved with?

594 7. What are the main advantages/opportunities you see in LFM/ELFM projects?

595 8. According to you, which are the main environmental benefits of LFM/ELFM?

5969 9. What main disadvantages/risks do you see with the realization of an LFM/ELFM project?

597 10. According to you, which are the main negative environmental impacts/risks of LFM/ELFM $598 \quad$ projects?

599 11. According to you, which are the main challenges for the realization of LFM/ELFM $600 \quad$ projects?

$601 \quad$ 12. What economic drivers and/or barriers can you identify?

602 13. What regulatory instruments do you know affecting LFM/ELFM projects?

603 14. Where do you see markets for the products/outcomes of LFM/ELFM? 
15. What societal challenges do you expect/have you experienced in LFM/ELFM projects?

605

16. According to you, which are the most influential actors when it comes to the planning and 606 realization of LFM/ELFM projects?

17. Who do you think is/should be responsible for regulating and/or communicating

608 LFM/ELFM?

18. How do/does the authorities/your institution deal with uncertainties concerning LFM/ELFM projects?

19. How happy are you with the role of institutions/authorities when it comes to LFM/ELFM? 